\title{
An Elusive Search for Peace:The Rise and Fall of the World Federation of Education Associations (WFEA), 1923-1941
}

\section{Harry Smaller}

York University

\section{ABSTRACT}

In the aftermath of the First World War, the National Education Association in the USA actively organized to establish an international association of education associations. The founding conference was held in San Francisco in 1923, and first biennial conference of the newly-formed World Federation of Education Associations (WFEA) was held two years later in Edinburgh, Scotland. Although the organization was able to hold six subsequent biennial gatherings, attracting large delegations, almost from the outset it seemed to be riven by tension and dissent, both internal and external. As a result, it did not even survive its second decade, disappearing from view during the Second World War. This paper explores the rise and fall of the WFEA, suggesting that the seeds of its failure were sown even during its inaugural gatherings.

RÉSUMÉ

À la suite de la Première Guerre mondiale, la National Education Association aux États-Unis travailla activement afin d'établir une association internationale des associations d'éducation. La fondation a eu lieu à San Francisco en 1923 et le premier congrès biennal de la nouvelle World Federation of Education Associations (WFEA) se déroula deux ans plus tard à Édimbourg en Écosse. Malgré le fait que la Fédération ait pu tenir six congrès biennaux attirant d'importantes délégations, l'organisme fut affaibli dès ses débuts par des tensions et des désaccords internes et externes. En conséquence, la Fédération n’a pu survivre très longtemps et disparut durant la Seconde Guerre mondiale. Cet article retrace la montée et la chute de la WFEA et démontre que les germes de son échec étaient présents lors de ses premières réunions.

\section{Introduction}

In the words of Augustus Thomas, Commissioner of Education for the State of Maine, July 20" 1925 was a "glorious" day for Edinburgh, for Scotland, and for education around the world. As the opening speaker at the first "Biennial Meeting" of the World Federation of Education Associations (WFEA), the founding president of the association noted that he was pleased be able to accept the "invitation of the 
Educational Institute of Scotland to make Edinburgh the place of meeting," and to note the "high class of delegates who make up this conference." 1

In his opening address, Thomas briefly covered a number of themes and issues relating to the organization, and to the upcoming deliberations during the business sessions of the conference. Of prime importance, he claimed, was the achieving of global peace. "The greatest problem before the world and the aim most devoutly to be wished is universal peace. . . There is great importance to be attached to mutual disarmament," he noted, " but peace is of the heart, and until we have developed a sense of justice and the spirit of goodwill, we shall be disappointed now and then. In this, education seems the hope of the world." 2 To do this, he proclaimed, "It is the purpose of this great organization to effect a closer unity of organized educational forces throughout the world, to stabilize so far as education can the trend of the future, to provide a sane and courageous leadership in directing the advancement of the human race. ${ }^{3}$ However, he forewarned that, in doing so, the Federation "must never be allowed to become entangled with political contentions . . . It must occupy a broad plain of universal truth and must steer clear of those rocks upon which nations may split." 4

He reminded delegates of the antecedents of this gathering - the "World Education Conference for Peace" which had been held in San Francisco two years earlier, and at which "a definite programme of procedure" had been developed in order to "secure international cooperation in educational enterprises" and to "promote the interests of peace throughout the world." This initial "programme" consisted of no less than twenty recommendations, ranging from the establishment of a world university, international scholarships, a universal library bureau, and advocating that educational attachés be placed in every nations' foreign embassies, to promoting character education, "improved professional training of teachers" and provision of more support for educational opportunities for rural children. However, clearly significant among these recommendations was one which was immediately enacted at the 1923 gathering - the formation "of a permanent federation of educational associations, to be named the World Federation of Education Associations."

Thomas endeavoured to assure the Edinburgh gathering that progress had already been made on at least some of these recommendations, including "an awakening in the relief of illiteracy," "a beneficial study of world contacts," a "beginning ... in the dissemination of educational information through magazine articles, and the exchange of periodicals." Unfortunately, he added, "[w]e have been handicapped to some extent by lack of resources," but he quickly added that "in due season [this] will be overcome and more rapid progress will be made."5

One announcement which Thomas was pleased to make was the fact that, following the 1923 conference, a wealthy American industrialist had offered \$25,000 to be used as the prize for the best educational plan calculated to assist in achieving global peace. This competition had been held, and a winning plan, to be entitled the Herman-Jordan Peace Plan, ${ }^{6}$ had been selected by a blue-ribbon judging committee. As he explained, 
This plan has been printed in agenda form and distributed among the delegates so that you may study it and understand its importance. Such a plan should further world understanding, world friendship and advance the cause of peace - one which would be discussed in detail during the conference. ${ }^{7}$

\section{Edinburgh as the Template for Subsequent WFEA Biennial Conferences}

This first (delegate-only) "Delegate Assembly," as well as the open, public "Welcome Meeting" held in the evening ("a gathering of over 2000 people") certainly set the template for the remainder of this conference, as well as the six subsequent biennial gatherings held in other major world centres. Welcoming speeches from assorted dignitaries and officials were followed by expressions of gratitude from various visiting officials of member organizations of the WFEA, along with their hopes that, in the words of one delegate, "we who to-day represent the teachers of our various home lands remain true to the vision embodied in the creation of this World Federation will the children of to-morrow realise the ideals set forth in that vision." "Also featured at the Welcome Meeting was a "programme of music" featuring "appropriate hymns with full orchestral accompaniment ... sung with great fervour by the large audience led by a choir of students from Moray House Training College." As the Conference Proceedings noted, "Probably the hymn which most attracted the audience by its suitability" included two "significant verses":

These things shall be: a loftier race

Than e'er the world hath known shall rise

With flame of freedom in their souls

And light of knowledge in their eyes.

Nation with nation, land with land,

Unarmed shall live as comrades free;

In every heart and brain shall throb

The pulse of one fraternity. ${ }^{10}$

The main thrust of the week-long conference consisted of "Group Meetings," with the eleven "groups" being based on major educational themes (pre-school, primary, secondary, etc). At these meetings, educational "experts" from across the globe gave prepared papers to relatively large audiences, followed in many cases by considerable discussion. These presentations ranged widely, and included such topics as "School Hygiene in Japan," "Education and International Relations" and "The Relation of Illiteracy to World Problems." Out of these presentations and discussions frequently came proposals and resolutions which, if agreed upon by the group, were sent on to the delegate assemblies to be considered for inclusion as official policy or program. These resolutions were numerous and extensive, some seemingly far-reaching in effect. For example, the "Elementary Education" group had five successful proposals, including that "the World Federation of Education Associations affirms its belief in the potency 
of Goodwill Day as a factor in creating and fostering an international understanding among the children of the world." By comparison, the "Character Education" group was clearly vexed with the problematic cross-cultural complications of a concept such as "character." After considerable discussion and debate, involving a number of proposals and sub-proposals, only a statement in principle could be approved: "That the World Federation of Education Associations affirms its belief in the importance of character training in education, and refers the subject to appropriate committees for future consideration in all sections of the Federation Conferences." In total, twenty resolutions were adopted at the Edinburgh gathering. ${ }^{11}$

In addition to the numerous "Group Sessions" the conference also involved a number of other activities. First, scattered throughout the week were seven "Public Meetings" involving invited speakers giving prepared lectures on a variety of themes such as "Education in Greece," "Chinese Education: Its Historical and Present Conditions," and "Who shall mould the Mind of America?" Late in the conference, virtually an entire day was set aside for two consecutive "Plenary Sessions." The first plenary began with "Addresses by Delegates from Various Countries," and reports on the work of the League of Nations. ${ }^{12}$ Delegates from countries interested in hosting the 1927 biennial meeting were encouraged to come to the stage to extol the virtues of their respective locales. ${ }^{13}$ However, the majority of the first session and virtually all of the second was used up in discussions and debates of the reports and resolution proposals, and preparation of a final report on those resolutions which were approved for consideration by the highest authority of the organization, the Delegate Assembly.

Finally, on the morning of the last day of the conference, the second of the two official delegate assemblies was held (the first being the opening session a week earlier). There were a number of items on the agenda: presentation and debate on the report from a special committee which was struck at the start of the conference to deal with the proposed peace plan announced at that time by the president; revision of the constitution; treasurer's report; election of WFEA executive and board of directors. Last but certainly not least, the delegates spent considerable time wrestling with the proposed policy and program resolutions one more time, eventually agreeing on a package.

It should certainly be noted that the conference was not all "work." Delegates also participated in a number of other formal and informal activities during the week-daily luncheons with speakers, full-day excursions, civic receptions, films, concerts and special church services in the various denominations. In addition, as there were "among the delegates many Freemasons . . . arrangements were made for their attending a special meeting of the Lodge of Edinburgh.” Finally, a "dozen Golf Clubs in Edinburgh gave the courtesy of their greens during the period of the Conference."14

The Edinburgh gathering ended a week after its auspicious beginning — with a final "Valedictory Meeting" where dignitaries, such as Princess Radziwill of Lithuania, Madame Dreyfus-Barney of France, Dr. P.W. Kuo of China and Lady Leslie Mackenzie of Scotland, among others, thanked the organization for its wonderful work to date, and exhorted it to continue its efforts into the future. ${ }^{15}$ As the official record notes, "The proceedings closed with the singing of 'Auld Lang Syne."'16 
There is no question that many, if not all delegates returned to their homes firm in the belief that the conference had been a success. They had reaffirmed the "global peace" vision of the organization, they had approved a revised constitution and a number of policy statements, and they had elected a new executive and board of directors to take charge. They had agreed that the organization would henceforth consist of a whole array of education-related "sectional working groups," reflecting not only the major themes of Pre-school, Elementary, Secondary and College/University schooling, but also 17 other sections, ranging from Health Education and Adult Education to Illiteracy, Preparation of Teachers for Co-operation and Goodwill, Motion Pictures and Parent-Teacher Associations. For each section, a chairperson had been identified, and charged with inter-conference sectional activity, as well as being responsible for arranging a program of speakers for the ensuing biennial event. Finally, and in addition to the "sectional working groups," they had approved the recommendations from the committee struck to examine the proposed Herman-Jorden peace plan, agreeing that five committees should be established, each to take up one major aspect of the plan, and that the "appointment of the committees be left to the President and the Board of Directors." 17

Published post-conference reports from delegates who had attended the Edinburgh event - at least those from the West - seemed to reflect this belief in the success of the conference, and the future of the WFEA. A lead editorial in the September issue of the journal of the British Columbia Teachers' Federation claimed that it "was probably the most outstanding educational gathering ever held."

The spirit of fairness and equity together with the necessary factor of compromise shown by all the delegates proves conclusively that educators from the world's various countries have really embraced that spirit of goodwill and friendship which will remove mountains of prejudice and intolerance and will ultimately have a far reaching influence in moulding the minds of future generations along lines of international amity. ${ }^{18}$

Similarly, a delegate from Ontario, Marion Whyte, reported in her union journal on the "the most important event of the past summer," the advantages to discussion provided by the "international complexion of the groups," and the unanimous agreement among delegates on "the importance of teaching all subjects so as to promote world harmony." ${ }^{19}$

A delegate representing the University of California was equally effusive, in his coverage of the conference.

For an entire week these representatives of the teachers of the world broke through the barriers which time and space have built up between human beings and without entirely forgetting the differences of viewpoint occasioned by national, social, political, religious philosophies and theories, - they lay all these to one side for the time being, so far as humanly possible, — and devoted their thought and energy not to a wrangle over differences but rather to a study, 
consideration, and assembly of 'those points of agreement universally valid' and necessarily true for the welfare and upbuilding of the whole human race. The entire conference proceeded in the spirit of a common humanity. ${ }^{20}$

Edinburgh was just the first of a number of biennial WFEA world conferences; six more were to follow, held in Toronto, Geneva, Denver, Dublin, Oxford and finally Tokyo in 1937. Like the Edinburgh gathering, each week-long event involved participants from around the world, numerous symposia, panels, key-note addresses and association business meetings, as well as the numerous receptions, cultural events and excursions. While the official number of voting delegates representing each member association or organization was limited by constitutional formula to a maximum of 50 based on association membership, participants attending one or more sessions at these events ranged upwards from one to several thousand. ${ }^{21}$ If one were to judge solely from the numbers of delegates who turned out for each biennial event, and the nature of the official post-conference reports, one could certainly be left with the impression that this was a highly successful organization, highly effective in achieving its professed aims and objectives. In addition, in reading first-hand reports from delegates to this and subsequent WFEA conferences, one would also conclude that the social/travel aspects of attending these international events also figured significantly in the overall "success" of WFEA. For example, a published post-conference report from one Canadian delegate to Edinburgh consisted largely of describing the "beautiful hospitality of the Scottish teachers and of the people of Edinburgh," along with detailed descriptions of the receptions, the "delightful concerts." and excursions which "filled all our spare time and even tempted us away from section meetings." 22

In spite of all of this "success" however, the historical record also makes three points clear: first, that the organization did little to achieve many of its goals (at least, its stated goals), secondly, that it suffered significant tensions and dissent, both within and without, almost from its beginning, and thirdly (not unrelated), that it had a relatively short life-span as an international organization. I would argue that, even at its first official biennial conference, there were a number of indications suggesting a clouded future, and relatively early and ignominious demise. In fact, some of these may have been intimated even earlier, before, during and immediately after its founding conference held in San Francisco two years earlier, to which I turn now.

\section{Founding of the World Federation of Education Associations (WFEA)}

It is important to note that the creation of the WFEA very much lay in the hands of the National Education Association, founded in the USA in 1858. While boasting the largest membership of classroom teachers in the country, for at least its first 100 years of existence it was very much controlled by senior education officials, university faculty members and government officials, virtually all white males, conscious of their professional status. From NEA's perspective, founding the WFEA was a natural outcome of its developing relations with national and international organizations. Well before the turn of the $20^{\text {th }}$ century the NEA had already expanded its political 
engagement from local, state and national politics, to becoming active in international relations as well. In the words of a more recent NEA president,

[The NEA] saw its international perspective develop in tandem with the country's rise as an international political and economic power in the early $20^{\text {th }}$ century ... These views included expansion of U.S. influence and educational systems to the country's new protectorates in Cuba, Puerto Rico, and the Philippines. ${ }^{23}$

Perhaps to this end, the NEA made a point of inviting education officials from other countries to attend their annual conferences, and by 1915 it was able to boast of having appointed a relatively large number of these foreigners as "Honorary VicePresidents" of the NEA. ${ }^{24}$

In the immediate post-war period internationalism continued to animate NEA officials - particularly in parallel with the efforts of Western governments, agencies and institutions to create, in the common parlance of the time, a "new world order." As one NEA president of the time noted, their organization was already forming a plan to call an international conference of educators, even

As the World War was drawing to a close. It seemed to the members of the National Education Association that the governmental authorities that were charged with the great task of setting the disturbed world on its new course were too occupied or too hurried to provide a place for consideration of education as a practical instrumentality for the creating of a new world order... [Thus] The National Education Association took steps to call such a conference as this.

He went on to say however, that "a careful inquiry" undertaken immediately post-war led official s to the conclusion that it would be still too early for "many of the older States and most of the new ones" to send delegates." Thus, "to ensure that such a conference [have] the advantage that should be gained at such a world gathering," it had been put off at that time. ${ }^{25}$

In 1920 the NEA established a Foreign Affairs Committee, chaired by Augustus Thomas of Maine (subsequently to become the founding president of WFEA). At their subsequent annual convention, on the committee's recommendation, the NEA agreed to sponsor and organize an international event, the "World Education Conference for Peace," to be held in San Francisco in the summer of 1923, in the three days leading up to their own annual convention. During the preparatory year, invitations were sent out to "educators from every civilized country of the world," a package which included a letter of welcome and invitation from the president of the United States. ${ }^{26}$

Judging from the historical record of the 1923 event, global peace was first and foremost on the minds of most of the delegates, and seemingly the main reason why they had come together. ${ }^{27}$ In the build-up to this global conference, organizers made 
a point of emphasizing that the goal of achieving peace was forefront in their minds. Pre-conference releases to the local and national press certainly reflected this domain, and were duly reported. For example, on the eve of the opening session, the San Francisco Journal announced that "Dr. Joseph Swain, special representative of the World Peace Foundation ... will welcome the foreign delegates to the conference" in one article, while another was headed "World Meet on Education has High Aim: War Abolition Through Education, Main Objective of Sessions Opening Tomorrow.” 28

Even in the promotional material suggesting that there were also other educational aims for the gathering, organizers were careful to tie these other themes to the issue of peace. For example, sessions on issues relating to children's health were buttressed by "the close cooperation which should exist between nurse, teacher and physician" in achieving education for peace. ${ }^{29}$ Similarly, aspirations to establish a "World Illiteracy Board" were supported with the claim that "no satisfactory progress can be realized leading toward universal peace and happiness until this condition [global illiteracy] is removed." 30

Like the succeeding conference in Edinburgh, there was no question that, to the organizers at least, it was an outstanding success. According to the official record, the gathering attracted 189 delegates from 40 countries other than the United States,"31 and was opened by welcomes from the usual array of political, cultural, religious and educational dignitaries. Themes of peace and international relations certainly permeated most of the speeches and other activities. By the end of the conference, of the 74 resolutions which were debated and passed, over $60 \%$ of them -44 in total - fell within the categories of "International Co-operation," "Conduct Between Nations" and "International Ideals." Clearly, the aftermath of the war, and the role which schooling might play in promoting peace, were forefront in the minds of the delegates.

Motions were also passed to establish the World Federation of Education Associations (WFEA), with plans to hold a world assembly every two years. Committees were established, ${ }^{32}$ Augustus Thomas was appointed president, and an executive and board of directors selected to carry the work of the organization forward. The conference closed with the mounting of a massive "pageant" involving costumes, music and dance representing various nations of the world, presented on a "great staircase . . . erected for this purpose," and telling "the story of a world desire for peace and the part that the educational forces are playing in this." 33 Judging from all of these reports, it would seem that the delegates returned to their home countries, at least some harbouring the strong belief that global peace and understanding would become, and remain, a prime objective of the newly founded organization. The NEA had been successful in its aims of founding an international organization, one which was able to organize a number of large subsequent biennial gatherings of education officials from many parts of the world.

\section{Why the short lifespan of the WFEA?}

In spite of these seeming successful biennial events, it is also clear that the organization survived for less than twenty years. Its eighth biennial gathering held in Tokyo 
in 1937 (in itself a controversial event, given Japan's invasion and continuing war in Manchuria $^{34}$ ) was its last official conference. While an event was in the works for Rio de Janeiro for 1939, a military coup resulted in its cancellation. ${ }^{35}$ As an alternative, a seven-week "good-will" cruise by chartered luxury liner, involving short stops in several Latin American countries, was held July/August of 1939. From 1937 to 1941 the organization maintained a bi-monthly journal, but soon afterwards it quietly folded up.

In retrospect, it seems clear that the WFEA had not been able to attract the broad interest and membership that its founders had hoped for - not only in the South, but in many parts of the North as well. There were, I would argue, a number of reasons for this inability to thrive. ${ }^{36}$ Further, I would suggest that the seeds of this failure might well have been apparent at the outset — in the initial 1923 and 1925 gatherings.

\section{a) USA-Centric Bias of the WFEA}

First, I suspect that the major reason for the ultimate failure of the WFEA lay in the realm of international politics. Although the organization continually espoused the need for global partnership throughout its existence, the leadership of the organization held a very distinct geographic bias - not just Western, but much more specifically USA centered, supported where useful by specific sectors within the British dominion. This bias manifested itself in many ways, not the least of which was the structural control of the organization - in the composition of the executive and board of directors (predominantly Americans), and in the location of its headquarters (USA). In addition, a disproportionate participation of delegates to the biennial conferences came from this centre. At the Edinburgh gathering for example, participants from North America and Great Britain constituted $85 \%$ of the entire delegate assembly (1037 of 1222). Subsequent conferences reflected this same disproportionate skewing. ${ }^{37}$

While officials of the National Union of Teachers in Britain were directly involved in WFEA from the start, attempts to draw involvement from other teachers' associations, even in Britain or Western Europe, including holding three biennial conferences there (Edinburgh, Geneva and Oxford), met with little success. The major women teachers' organization in England, the National Union of Women's Teachers, refused to join, even though they were actively involved in peace efforts, both in Britain and internationally. Similarly, two long-standing European-based organizations, The International Federation of Associations of Secondary Teachers and the International Federation of Teachers' Associations, both with histories extending back well before the First World War, refused direct involvement throughout WFEA's existence. $^{38}$

In addition to these structural controls, this Western-centric bias also expressed itself very much in the culture and discourse of the organization and its conferences - in ways which may well have dissuaded teachers and educators from the Third World from joining WFEA, beyond just the financial costs of membership and of participating in the biennial events. Comments made by officials, even during the 
opening sessions of the first biennial event in Edinburgh, might have served notice of the political bearings of the leadership, not ones which would speak sympathetically to regional populations which were struggling under colonialism and oppression from the Centre. At the outset of his opening address on the first day, the President noted that was

[I]nteresting also to meet on British soil, because the British people have interests in every part of the world and have come more directly in contact with all peoples than any other nations. Their business interests have necessitated a sympathetic policy in dealing with peoples of other lands, and the spirit of cooperation has necessarily been one of the chief features of these associations. ${ }^{39}$

Similarly, in welcoming the participants to Scotland, Professor W.P. Paterson, Dean of the Faculty of Theology at Edinburgh University and Ex-Moderator of the Church of Scotland, clearly understood the dominant forces in the room, in proclaiming that "I do not believe that there are any people that has brought more of a conscience into International relations than the American people," a claim which, while bringing applause from some of the delegates present, may not have pleased everyone present. ${ }^{40}$ While it is difficult to assess the nature of the social relations among delegates from North and South in their informal gatherings, it seems clear that at least some, if not many, of those from the North carried these same beliefs of superiority. In his post-conference summary of one of the important debates, one U.S. delegate was patronizingly explicit in describing his delegation's superior views, and the ways in which they were able to steer the decision-making:

The delegates from old-world nations seemed unable to grasp the fact that an individual may be loyal and devoted to his own nation and at the same time expand this same loyalty and devotion to include races and peoples other than his own.... The delegates from the United States, and some of those from Great Britain, found little or no difficulty in harmonizing the two conceptions and took the lead, for the most part, in aiding the conference to arrive at such conclusions as were finally agreed to and accepted in executive session. ${ }^{41}$

This culture of strong ethnocentrism seemed to dominate over the entire twodecade life of the WFEA. Even in the dying years of the organization, one American official of the WFEA was to report back from the final biennial conference that "we have met these men and women from the uttermost parts of the earth. We have looked into their faces and we have taken them by the hand. We find that they think as we do." ${ }^{2}$

\section{b) Competition/Overlap with other International/Education/Peace Organizations}

The WFEA was certainly not alone on the international scene, either in relation to representation of teachers and educators, nor in relation to its professed interests in achieving global peace. First, as noted above, a number of European teachers' organizations chose not to join in. ${ }^{43}$ Secondly, the other large teachers' association in the USA, the American Federation of Teachers (AFT), stood in perpetual competition (to 
this day) with the NEA, for membership and on most matters. Although it took up a (very reluctantly offered ${ }^{44}$ ) membership in the WFEA by 1927, by the mid-1920s it was also to begin involvement with the International Trade Secretariat of Teachers, a sub-group of an international labour union organization centred in Europe, entitled the International Federation of Trade Unions, to which the American Federation of Labour, the AFT's parent organization, was affiliated. As discussed more fully below, a major difference between the WFEA and the international teacher union movement was the former's insistence on promoting the "professionalization" of state schooling everywhere, as compared to striving to enhance both the material conditions of teaching, and teachers' voice in determining schooling routines.

Another source of probable difference, if not tension/conflict, were the organizations with the mandate of promoting the British Commonwealth specifically, many of which were particularly active during the 1920s and 1930s. In fact, during the same 1925 summer, four separate groups of teachers from England spent some weeks visiting their counterparts in Canada, under the auspices of the League of Empire, the Overseas Education League, and two English teacher unions, the National Union of Women Teachers and the National Union of Teachers..$^{45}$ During this time as well, a number of gatherings of the "Imperial Education Conference" were also being held (1907, 1911, 1923) - a network of organizations closely resembling those involved with the WFEA, but only from nations and colonies of the British Commonwealth. Session topics clearly demonstrated the essential purpose of the network - with titles such as "The Teaching of Geography from an Imperial point of view" and "On some aspects of the Teaching of Imperial History." ${ }^{6}$ Promoting, at the same time, a new international education network centred within a now-competing empire was probably seen as somewhat counter-productive, to say the least.

Russia and the newly-formed Soviet Union certainly constituted at least one entire region which did not participate in WFEA activities throughout the latter's existence (and were probably not invited in the first place). One reason for this may lay in the strong Western domination of WFEA, at a time when many Western governments' official opposition to these political developments in the newly-formed Soviet Union was well-known. The fact that, at the Edinburgh conference, a representative of "Russian Teachers Union abroad" and a "Russian Educational Bureau" located in Prague was invited to give a speech ${ }^{47}$ certainly symbolized this bias and undoubtedly soured any future relations with the Soviet Union, even if WFEA officials became so inclined. ${ }^{48}$

Finally, while national and international peace organizations proliferated in the post-World War One era-including ones strongly supported by national teachers' associations, such as the "Teachers and World Peace" conference in London, and the "World Peace Conference" in Brussels, both held in 1936,49 seems clear that, in spite of WFEA's public claims that global peace was its main objective, the executive of the WFEA were not interested in participating in any of these organizations or activities. I have come across no records of any approaches they may have made, or responded to, in that regard. While one is left to ponder why this was the case, NEA officials' concerns about "their" organization being involved with any dubious (read: progressive, 
or left-leaning, or simply non-USA oriented) organization may well have been part of this issue. However, as noted above (footnote \#10), they seemed to eschew even "legitimate" international, ecumenical, religious-based peace organizations.

\section{c) Gender Relations within the WFEA}

A third reason for the ultimate failure of the WFEA can certainly be attributed to issues of gender relations. In spite of the fact that a majority of primary school teachers, especially in the North, were female at this time, there is no question that male officials dominated virtually all aspects of the organization - its executive and board of directors, as well as those chosen to speak or present papers at their biennial conferences.

The only female identified as being active on the planning committee for the Edinburgh event was Mary Tweedie, a Scottish headmistress - and only, one can presume, because she was serving that year as President of the Educational Institute of Scotland, the official sponsor of the Conference. In this capacity she was allowed on the stage for the plenary sessions, along with the male dignitaries (and a few female elite), to welcome the delegates to Edinburgh at the opening session. In her welcome, she was quick to note the gender disparities. "I rejoice in the hazard — for it is a hazard - that has put one woman at least amongst those who are to welcome you here to-night. . . . I can assure you that the women of Scotland have worked shoulder to shoulder with the men in the interests of education." ${ }^{50}$ Regardless, her polite admonishments seemed to have no lasting effect, at least on the structures of the organization. By the end of this conference, a new Executive and Board of Governors were selected, the former containing no women, and the latter, 2 out of a total of 17 . Two years later, there were still no female executive members; of the 24 "international" directors, only three were women (two from the USA and one from Scotland). ${ }^{51}$

One can only surmise that this clear image of gender skewing, along with the fact that few, if any classroom teachers of either gender occupied positions of authority in the WFEA, did little to engender support for the organization among teachers in the world's classrooms - most of whom, at least in primary schools in the West, were women. ${ }^{52}$

\section{d) WFEA as an Organization of the Educational Elite}

There is no question that the WFEA was very much populated and controlled, throughout its entire existence, by members of the educational elite - school system administrators, government officials, politicians, university faculty members, and officials of teachers' associations. At the same time throughout the history of the organization, officials lamented their inability to attract or involve classroom teachers in the organization's activities. This became even more apparent to WFEA officials during its second decade, when they began seriously to ponder why their organization had not achieved the overall success which they had hoped. As one official noted, publicly in a 1937 editorial in WFEA's journal, they had not been successful in attracting "the teachers that constitute the rank and file of our profession . . . to command the genuine interest of public school teachers." 53

One could easily surmise that few classroom teachers might have been interested 
in an organization which featured only (male) school and teacher union bureaucrats, university professors and government officials at its helm. In addition, participating in the biennial conferences held beyond their own city clearly entailed expenses well beyond the reach of salaries of classroom teachers, even those from the North, let alone the rest of the world. ${ }^{54}$

It is not inconceivable that classroom teacher antipathy to WFEA may well have resulted as well from another cultural aspect of the organization - a dominant belief in the primary importance of bureaucracy and bureaucrats in promoting "good schooling" and advancing bureaucratic, centralized school systems. There is no evidence of WFEA ever addressing fundamental issues of classroom teachers - particularly their material conditions, or their lack of voice in determining schooling policies, programs or practices - in spite of individual requests from delegates to do so. ${ }^{55}$ In fact, at the Edinburgh conference, Thomas was quite explicit on this matter, in an address relating to the overall control of schooling. Classroom teachers could not be "trusted" with involvement in decision-making about these matters. ${ }^{56}$

Related to this, there is no question that WFEA officials held a clear anti-union bias - one which might well explain their inability both to attract classroom teachers, or many of their unions where they existed. This dissonance within the WFEA centred around the organization's inability or refusal to accommodate discussion with teachers' organizations which had trade union cultures. ${ }^{57}$ As one American WFEA official noted in 1937, in attempting to explain the organization's failures, the NEA's

Method of promoting professional ideals and knowledge is acceptable and familiar only to the teachers of America - those of the United States and Canada. In other countries belonging to the Federation organizations are practically for the promotion of teachers' professional welfare in the sense of tenure, salary, pensions and similar rights; conferences are for officially constituted delegates. ${ }^{58}$

\section{e) WFEA's Struggle with Achieving a Viable Plan for Global Peace}

If one were to go by its public statements, the dominant rhetoric was clear: the WFEA was founded with the primary aim of working to achieve global peace. As noted, the original 1923 San Francisco conference was billed as the "World Education Conference for Peace," and a number of resolutions were passed to that end. Delegates to the 1925 Edinburgh gathering heard speech after speech exhorting the importance of global peace and the role which the WFEA could and should play in achieving it; to that end, detailed plans to operationalize the Herman-Jordan Peace Plan were developed. Subsequent conferences continued to emphasize these matters. However, as the decade of the 1930s progressed, it became increasingly clear to the officials and members of WFEA that even with (or because of) its proliferation of committees, the Herman-Jordan venture was not only totally unsuccessful in achieving these aims, it, and the WFEA at large, was even unsuccessful in mounting an effective campaign. ${ }^{59}$ 
To be sure, given the military and political structures in place, nationally and internationally, one could easily question whether teachers and teacher organizations, as numerous as they were in many nations of the world, could actually provide effective leverage against these larger forces, locally or globally. In addition, the onslaught of the economic depression of the 1930s might well have affected whatever capacity teachers and their organization had to mobilize on these issues. As well, while the increasing militarization and polarization among nations in the 1930s may have served to incite some teachers to even more pro-peace activity, it could just as well frustrated and discouraged many others from continued commitment. Evidence from teachers' international peace efforts leading up to the First World War made it clear that, as governments of individual nations began to take sides and prepare for war, it certainly became more difficult for classroom teachers, and their association leaders where they were so inclined, to speak out against these measures, at risk of disapproval, persecution, or worse. ${ }^{60}$ At the same time, I would argue that the reasons for WFEA's failures lay also within the organization, in a number of ways, including the contradictory and/or ambivalent positions held about the purpose and mandate of the WFEA, its insistence on maintaining a very specific belief about the causes of war, and about the best approaches to take in working towards achieving global peace.

\section{Purpose and Mandate of WFEA}

It is interesting to note that, in spite of the expressed concern about working directly to achieve global peace voiced at the 1923 founding conference of the WFEA in San Francisco during the formal speeches, discussions, and in the motions passed, it would appear that this explicitly stated purpose quickly disappeared from any of the formal plans emanating from the event, or indeed from the subsequent comments of the organization's newly elected officials. For example, James Hosic, professor at Teachers College Columbia, and official secretary of the founding 1923 conference, stated clearly in his post-conference report that "the Conference was not a peace conference, nor did it seek any new political relations as the outcome of its labors." Rather, the new organization would now "work for the 'promotion of justice, good will and friendship of nations through education." 61

Further, in the "Proposed Articles of Incorporation of the WFEA," reference to "peace" appears only as the final mandate of an otherwise lengthy list:

The purposes for which such Corporation is to be formed are to promote the cause of education and to elevate the character of teaching throughout the world; to secure international cooperation in educational enterprises; to foster the dissemination of information concerning the progress of education in all its forms among nations and peoples; to advise and promote suitable and effective means to bring about closer co-ordination the various agencies in every civilized country which have to do with education; to cultivate international goodwill, and to promote the interests of world wide peace. ${ }^{62}$ 
By the time of the first biennial conference in Edinburgh, these alternative aims were solidified within the permanent structure of the organization, and within the structure of all of its ensuing conferences. While the Herman-Jordan committee was given time at each biennial conference to report on their activities (or lack thereof), it is clear that the main import of the organization lay in the 20 educational "departments" which were established - Pre-School Education, Rural Education, Teacher Training, etc. Presentations and discussions during all subsequent conferences focused primarily on what was needed in the way of world-wide improvements within these various educational domains. While there was sometimes reference to how, in turn, global peace would be enhanced by these improvements, for the most part these improvements seem to be needed for their own purposes, in enhancing "good" (i.e. Western-modeled) education, and in enhancing the larger state schooling systems themselves. ${ }^{63}$ While retaining the appearance of being the raison d'etre of the organization, judging from the content and activities of all of the biennial conferences, achieving global peace occupied, at best, a very secondary goal in the minds of many, or most of the WFEA officials.

\section{Dominant Beliefs in the Causes of War, and the Resulting Educational Program of the WFEA}

To the extent that promoting global peace was at all a WFEA objective, the dominant position taken by its officials on the underlying causes of war, and therefore what had to be done to correct this, is also worth examining. As Augustus Thomas, chairman of the San Francisco conference, explained in his keynote 1923 conference speech,

So long as there is hatred or malice or jealousy and revenge in the human heart, we shall find it in the heart of nations. So long as we find it in the hearts of nations, we are liable to find men and nations clashing upon the battlefield. . . . We must have the spiritual values in order to back [up "peace treaties"] and in order to get the spiritual values to back up these great movements we must await the longer process of education. . . . In order, therefore, to change the ideals of the nations we must begin with the child when he first becomes teachable. ${ }^{64}$

These publicly-described beliefs remained unchanged among WFEA officials throughout the entire existence of the organization. In his opening remarks at the Edinburgh event two years later, Thomas was to continue promoting this principle, by quoting from Ella Blair Jordan:

In hearts too young for enmity,

There lies the way to make men free;

When children's friendships are world-wide

New ages will be glorified.

Let child love child, and strife will cease,

Disarm the hearts, for that is peace. ${ }^{65}$ 
As compared to this singular viewpoint held by the leadership, there were certainly instances in the official record of individual delegates wanting to suggest that there were, perhaps, other causes as well for war. However, these opinions certainly carried no weight in the ongoing discussions and actions (or lack thereof) of the organization. Mr. Edwards of England, for example, found no response to his assertion at a session of the 1927 Toronto gathering, that "the roots of war to me are economic and the lack of co-operation. I deliberately state that wars are caused by economic discontent and the desire of economic development of nations. . . The cause for war being economic, the remedy must be economic, in my view." ${ }^{66}$ Clearly, his "view" was completely antithetical to the dominant organizational, "it's all in the individual hearts and minds," ideology.

\section{Methods for Achieving Global Peace}

Any actions to be taken towards achieving this objective were also clear in these officials' minds. WFEA would work at two main levels "to promote international understanding and goodwill through education." 67 Within the organization, and throughout its formal and informal interactions during and between biennial conferences, all attention would be given to the importance of developing this one happy family approach; discussions and decisions were to be undertaken solely through friendly interaction, decisions made by consensus, without antagonizing any particular group. To do otherwise, it was held, would be to engage in "politics" — which was clearly undesired, at least by those in charge.

Accordingly, they claimed, at the global level education would be improved, resulting in students everywhere "disarming their hearts." As an editorial in the WFEA journal noted, "Promoting personal acquaintance among teachers and by revealing a knowledge of educational ideals and of the practice and experience of other countries [would serve as] the chief means of realizing this purpose." ${ }^{68}$ As a result, it became clear that the committees identified under the Herman-Jordan peace initiative, as well as the other major educational program committees of WFEA (curriculum, textbooks, teacher training, etc) should focus their discussions and recommendations on policies and programs aimed at "disarming the hearts" of students worldwide. This, in short, was to serve as the organization's educational program. Clearly, as WFEA official were to continually warn, this would not be a quick engagement. What was required, in the first instance, as Thomas pointed out to the delegates at the Edinburgh conference, was a lengthy "scientific and educational study . . . is wise, and no one who is interested in the broad outlook of the profession can find fault with it." ${ }^{69}$

Thomas's prediction of slow progress was certainly fulfilled. Two years later at the 1927 Toronto conference, and perhaps in response to those were beginning to "find fault" with lack of progress, Thomas stated that "If there are those who think we are to jump immediately into a new world order, actuated by complete understanding and brotherly love, they are doomed to disappointment." What was needed, he maintained, was a long process of education "...until the cobwebs of the old order are brushed out of the minds of the people of all lands.”70 
However, by the time of the biennial conference held in Oxford a decade later, there was strong disagreement over the work which the peace committees had claimed to have undertaken in the interim. On the one hand, W.T. Longshore, Vice-President of the NEA, outlined in a lengthy "Looking Ahead" speech, a number of schools and school districts in the United States which had innovated new courses, altered existing ones, or at least "allotted a generous portion of time and material to the study of world problems." In addition, he listed other steps taken by the NEA to promote international understanding. ${ }^{71}$ However, in spite of this attempt at demonstrating success, Longshore himself had to admit that things were not all rosy. "Our review of some of the achievements of the past indicates only too clearly that most of our work still lies ahead of us." As well, he lamented the lack of support even from state level and local affiliates of his own teacher education association. ${ }^{72}$

More pointed critique of the program came during subsequent discussion at the session, mounted by Dr. Kuhlmann, Secretary of the Education Committee of the League of Nations. As reported in the official proceedings of the conference, he lamented that "We shall live in a fool's paradise if we leave this great world conference with the impression that education for world understanding and peace is to-day making headway in the world at large." 73

\section{Failings of the "Happy Family" Approach to Organizational Effectiveness}

Clearly, the stated organizational objective of working only in ways which maintained the "happy family" and "keeping neutral" approach among member organizations harboured severe limitations, even from the beginning. For example, at the 1927 conference when the debate became heated over the issue of military training in schools, Dr. Hardy of Toronto intervened, stating that "I think it would be most unfortunate to set the fires of division burning among us. . . if we can't agree on this kind of thing, [I suggest that we] confine our attention to things on which we can agree." ${ }^{74}$

This "keeping neutral" approach continued right up to the end of the WFEA — and, may well have been a major cause of its ultimate demise. Despite the growing global tensions during the 1930s, the mounting military aggression within and between nations, and the diminishing of hopes for peace, WFEA refused to take sides on any of these events. In spite of Japan's invasion of Manchuria in 1931, and continued aggression thereafter, officials insisted on continuing with its plans to hold its 1937 biennial in Tokyo. Even in the late 1930s and into the 1940s, its official journal continued to publish articles, such as "Aims in Nazi Germany" and "Education in Germany," which had been directly translated from original German academic sources. ${ }^{75}$ As the president of the WFEA explained in an editorial in September 1938 (clearly written in response to mounting criticism about this approach),

By recent vote of its directors as well as by its traditions of fifteen years, [we have] avoided discussion of all educational problems that deal directly with any of the political problems of the day.... World Education fully intends to be as 
objective as is humanly possible, including "wish[ing] not to stimulate negative attitudes toward Germany, which to many seems at present to be one of the chief champions of preparedness. ${ }^{76}$

\section{Conclusion}

In looking back on the pronouncements and activities of WFEA officials over the inter-war years, it is certainly understandable if one were to conclude that, in spite of their rhetoric concerning global peace, the real purpose of the organization was to promote Western-oriented professionalized, centralized, bureaucratized, patriarchal state schooling systems everywhere. Given this underlying objective (and the fact that the organization seemed to be totally ineffective in helping to promote global peace), it is understandable why classroom teachers, and even many local teacher associations, would eschew such a vision. During the 1930s, WFEA officials were increasingly forced to admit that their approaches had not been successful. An editorial in the post-Tokyo conference issue of Education World opened with the blunt statement that even the "officers" of the WFEA were "free to admit" that "the question of the main function of the Federation remains unclarified in the opinion of the educational public." While there was continued insistence that their "obligation [was] to assist in the development of international understanding and thence of international peace through education," there was also a realization that their "one method of obtaining this objective, that is through the mutual acquaintance of educators of various countries" was "wholly inadequate when judged in the light of our major objective."77

As the president remarked (seemingly without any apparent recognition of its contradictions), "[W] could not take a position regarding any controversial questions without causing a division in our own body and thus defeating the very purpose of our organization. ${ }^{78}$ One might assume from this statement, that the ultimate aim of his organization, in his mind at least, was to maintain a contented membership at all costs, over any direct interests of achieving global peace. Not suggested was another possibility - that the diminishing support for the organization could be attributed precisely to their inability to take up "controversial questions."

Reasons abound for the ultimate failure of the WFEA in promoting global peace, in spite of the well-meaning work of many hundreds, or thousands of classroom teachers in many nations, during these two decades. Whether more success could have been achieved by these teachers in their classrooms, supported actively by their unions and associations with better — or different — visions, remains a question, to be sure.

\section{Notes}

1 George C. Pringle, ed., Proceedings of the First Biennial Conference of the World Federation of Education Associations held at Edinburgh, July 20 to July 27, 1925 (Edinburgh: Scottish National [Conference] Committee Offices of the Educational Institute of 
Scotland, 1925), 1-2. Following each of WOTP's biennial conferences, extensive official "Proceedings" were published, ranging from one to five volumes in length; in addition, the WOTP published the periodical World Education between 1936 and 1941. Most of these publications remain available in one or more libraries/archives in Canada and/or the USA, and many were examined as part of the research undertaken for this article. Primary sources for this study also include other publications and papers of the WOTP as well as those of a number of Canadian and U.S. teacher associations and other educational associations, along with dominant press reports and personal archives. A wide variety and number of secondary source publications were also consulted. All specific sources are referenced when cited or quoted in the article.

2 Ibid.,13-14.

3 Ibid., 12.

4 Ibid., 6.

5 Ibid., 3-6.

6 Named after David Starr Jordan, former president of Stanford University (and former president of the NEA), the winner of the competition, and Raphael Herman, the industrialist who donated the prize money. This elaborate plan — initially and enthusiastically adopted, but ultimately abandoned — was based on establishing a number of committees of educators which would research and develop various ways in which state schooling systems could enhance international understanding.

7 Ibid., 10.

8 Ibid., 25.

9 Ibid., 52-53. It should be noted that no females appear to have occupied the stage of the first Delegate Assembly, and only two were asked to give greetings at the evening Welcome Meeting. All the remaining representatives of the teachers of the world allowed to speak in these two sessions were men, and all occupying high positions in education.

10 Ibid., 53-54. While this and all subsequent biennial conferences included opening and closing remarks, prayers, etc, by Christian church officials, to date I have seen little or no evidence of any direct relations/activities between any religious organizations and the WFEA over the latter's history - including even two major international religious organizations founded and operated on the hopes of achieving global peace - the "Church Peace Union" (founded and funded by Andrew Carnegie), and the "World Alliance for the Promotion of International Friendship."

11 Ibid., 914, 917.

12 While this and some subsequent biennial conferences included reports from and/or about the League of Nations, there did not seem to be any direct involvement of the WFEA with the organization.

13 The decision to select Toronto as the 1927 venue was made, post-conference, by the WFEA executive. It should be noted that, following the 1923 San Francisco meeting, Japan was in consideration for the 1925 event. However, as Thomas later explained, "We were invited to Japan, but then the disaster [earthquake] came and that had to be withdrawn" (World Federation of Education Associations, Proceedings of the Second Biennial Conference held at Toronto, Canada, August 7-13, 1927 [Augusta, Maine: WFEA, 1927], 862; hereafter, Proceedings, 1927.).

14 Pringle, Proceedings, 897, 898.

15 Perhaps the only sour point in this session occurred in the context of the German representation. Their spokesperson explained that "Professor Kerschensteiner, representative of the German Universities, had the intention to give a message to the Conference in the name of the German and Austrian delegation last Saturday, but unfortunately there was no opportunity." No reason was given for this "unfortunate opportunity," but Kerschensteiner's text was reproduced in the Proceedings, in which he 
stated that "The proceeding of some governments towards the German minorities living within their countries, that result in a suppression and closure of German schools, must be a danger to any international understanding" (Ibid., 863, 868).

16 Ibid., 867.

17 Ibid., 833.

18 The B.C. Teacher, Sept. 1925, 2.

19 Marion Whyte, "The World Conference," The Bulletin (Ontario Secondary School Teachers' Federation), 5, 4 (1925): 17.

20 L.A. Williams (University of California), "Edinburgh: A Retrospect," The High School Journal, 9, 1 (1926): 3.

21 Author/publisher unknown, 'World Federation of Education Associations' (mimeographed report on its origins, conferences, etc) [nd 1946?] 2-3; Archives of the Canadian Teachers' Federation, Ottawa (hereafter, WFEA, 1946). The overwhelming number of attendees at these conferences were "registered" but had no official or voting status - they consisted of members of related organizations, teachers incorporating the conference into their summer travels, and local teachers attending the sessions out of their own interest. For example, the President of WFEA announced halfway through the 1927 Toronto conference that "our registration shows about 7,500" (1927 Proceedings, 105). In fact, in total the WFEA throughout its existence consisted of only 25 "full members" representing only 13 nations (USA, Canada, 3 from the British Isles, Germany, Hungary, Greece, Japan, China, India, Malaysia and the Philippines). In addition, other educational organizations and recognized institutions of higher learning were accorded "associate membership," including some voting rights. Of the approximately 200 organizations in this category, well over $85 \%$ were located in the USA (WFEA, 1946, 21-22).

22 Whyte, "The World Conference,"18. One might assume that, for reasons of gender, Ms. Whyte made no reference to her involvement in golf, or the Freemasons' invitation.

23 Mary Futrell, Fred van Leeuwen and Rob Harris, "Toward International Advocacy," in Ronald Henderson, Wayne Urban and Paul Wolman (eds.), Teacher Unions and Education Policy: Retrenchment or Reform? (Oxford: Elsevier Ltd., 2004), 252. A centennial history of the organization published in 1957 cites the importance of a formal "alliance" of the NEA with the American Legion during this post-WW1 period, given their shared "objectives" of the "teaching of history, citizenship and patriotism" (Edgar Wesley, NEA: The First Hundred Years, The Building of a Teaching Profession [New York: Harper \& Brothers, 1957], 316).

24 NEA, Proceedings of the 1915 Annual Convention (Washington: NEA, 1915), 25.

25 Augustus Thomas, "Education for World Conduct," NEA, Report on the World Conference (Washington: NEA, 1923), 10.

26 Wesley, NEA, 359.

27 It is perhaps not surprising, given their close attachment to young people, that teachers - particularly in Europe - have historically been active in their attempts to promote peace. As historian Louis Dumas noted in 1953," after every big war teachers are more fully aware of the part that education plays in the outbreak of conflicts" (quoted in Frank Simon and H. Van Daele, "The International Teachers' Organisations until World War II," in Instruction, Education and Society in the 19th and 20th Centuries, eds. Marc Depaepe and M. d'Hoker [Leuven/Amersfoort: ACCO, 1987], 141).

Similarly, Frank Simon and H.Van Daele, in their 1987 article, claimed that, "as a dam against war violence, [teachers] made efforts for international rapprochement, mutual understanding, learning more about each other's daily pedagogical practice" (Ibid.). In his description of early international educational programs, Brickman suggests in his 1950 entry in the Encyclopedia of Educational Research that in the period from 1814 to 1914 there were over thirty proposals developed by educators and others for some 
sort of international collaboration on these matters (W.W. Brickman, 'International Education', in W.S. Monroe, ed., Encyclopedia of Educational Research [New York: Macmillan, 1950)], 617).

28 San Francisco Journal, 27 June, 1923.

29 Ibid., 1 July, 1923. "Medical Help for Children, Topic."

30 Ibid. "World Illiteracy Board Advocated." Seemingly not explored at this, or subsequent conferences, was the issue of this purported causal relation between literacy and peace. For example, no questions seem to have been raised about the claims of one 1923 delegate, Professor Ave of the Imperial University of Japan, who stated that "95 per cent of the people of Japan were literate..., and that illiteracy was not an important question in his country" (Ibid), given his country's concurrent massive re-armament program, and subsequent invasions of Manchuria and China.

31 WFEA, 1946, 2-3.

32 International Co-operation, Dissemination of Education Information, Conduct Between Nations, International Ideals and Health Education (WFEA, 1946, 2).

33 San Francisco Journal, 24 June, 1923. As it turned out, this "pageant" was to become a standard fixture of all subsequent WFEA conferences, with each successive venture clearly intended to outshine the previous one. Within four years, the conference held in Toronto featured a pageant attended by 10,000, "presented on four stages, rising above each other, about 1400 performers taking part." However, it seems that the peace motive had already been considerably downplayed; instead, the message was "a symbolic picture of the development of the world from savagery to civilization through the influence of education" (presumably, of the compulsory, state-imposed, professionalized teacher, variety) (The B.C. Teacher 7/1, Sept 1927, 29-30).

34 For further discussion of the Japan conference, see Harry Smaller, "The NEA, the WFEA, and the Teachers' World Conference on Peace, Tokyo 1937" (paper presented at the 2013 annual conference of the USA History of Education Society).

35 The new military regime informed the WFEA that, if held, the conference must confine its activities "to a study of the fine and liberal arts and the pleasures afforded in their country." (Education World, July 1939, 124).

36 In spite of concerted efforts over the years, in total, as noted above, the WFEA was able to muster full memberships from organizations located in only 13 countries, mainly North America and Europe (WFEA 1946, 21-22)

37 Pringle, Proceedings, 866.

38 On one occasion, at the 1935 WFEA Conference in Oxford, both of these organizations agreed to hold "Synchronized Conferences." However, they remained structurally separate throughout this time. To date, I have not been able to identify teachers' organizations existent at the time in other parts of the world (other than those few which joined the WFEA during its existence) which may have considered but ultimately rejected applying to the WFEA for membership.

39 Pringle, Proceedings, 1.

40 Or, the teachers in the South whom they claimed to represent. Ibid., 21-22. The term "civilized" in reference to particular nations permeated the discourse of the organization's activities from its very beginnings. For example, invitations to the founding 1923 conference were sent to "educators from every civilized country of the world" (Wesley, NEA, 359). At the Edinburgh event, the audience at the Welcome Meeting as informed by the chairperson that they represented "practically every country which can make any claim to be civilized" (Pringle, Proceedings, 26).

41 L.A. Williams (University of California), "Edinburgh: A Retrospect," The High School Journal, 9, 1 (1926): 4.

42 NEA, Report on the World Conference (Washington: NEA, 1923), 10.

43 While I have yet to access records from these organizations which might explain this 
disdain for WFEA, one can certainly assume that WFEA's USA-centric structure and culture might in itself provide sufficient motivation for Europeans concerned about the USA's increasing dominance in international affairs. Gender relations also may well have played a large role - to be discussed in the following section of this paper.

44 And only after considerable intervention by non-NEA officials of WFEA. See, for example, comments by then-WFEA vice-president Harry Charlesworth of the British Columbia Teachers' Federation, reminiscing some twenty years later about his efforts to have the AFT accepted into the WFEA. "[As I] had met many of their [NEA] leaders, I was fully aware of the difficulty confronting Miss. Borchardt" (the AFT representative on the WFEA executive) (Charlesworth to Kuenzli, April 12, 1944; Selma Borchardt Files, Box 18, Walter Reuther Archives, Wayne State University, Detroit).

45 The Bulletin (Ontario Secondary School Teachers' Federation), 5, 4 (1925): 1.

46 Report of the Imperial Education Conference 1911 (London: His Majesty's Stationary Office, 1911), 2.

47 Pringle, Proceedings, $734 \mathrm{ff}$.

48 During the second half of the 1930s a new group of WFEA officials did attempt to reach out to the Soviet Union, probably related to a larger (last-ditch) campaign at that time to enroll more national teachers' associations into the organization. Ironically, these actions may well have served to increase the mounting opposition to the WFEA expressed by some officials of the NEA, and their decision in the early1940s to, in effect, lobby for the demise of the organization. See for example, 19 February 1936, letter from WFEA Secretary-General to USSR Society for Cultural Relations with Foreign Countries. ("The U.S.S.R. is now a pioneer and a leader in many educational activities ... "). Selma Borchardt Files, Box 62, Walter Reuther Archives, Wayne State University, Detroit.

49 See, for example, the archival collection of correspondence of the National Union of Women Teachers during these decades for a broad description of these activities (Institute of Education, London).

50 Ibid., 41. She was asked to speak also at the final "Valedictory Meeting," where she once again commented sardonically on the gender disparities, even though she was "totally unprepared even for thought" (presumably, having not been notified ahead of time of the need to make a presentation). "I appreciate very keenly the privilege that you gave me, like a woman, of being in at nearly the last word, if not the very last ..." (Ibid., 864.)

51 Ibid., 810-811.

52 One can assume that gender relations played a large role in the Nation Union of Women Teachers' (Britain) continued rejection of the WFEA's repeated invitation to become a member (see, for example, letter to WFEA, 21 January 1925, Minute Book, NUWT Officers' Meetings, Archives, Institute of Education, London England). To be sure, the Proceedings from the 1925 Edinburgh Conference included comments made by women - however, they were clearly not teachers themselves, but rather representing class and status interests outside of the organization itself (eg. Princess Radziwill, Madame Dreyfus-Barney and Lady Leslie Mackenzie). One can only surmise whether gender relations also played a role in the WFEA's seeming lack of connection or involvement with the Women's International League for Peace and Freedom.

53 Education World, September 1937, p. 137. In fact, as I have argued elsewhere, there is very little evidence to suggest that, for whatever reasons, national teacher unions, at least in the U.S. and Canada, were generally interested in promoting, or even mentioning their international activities to their state/provincial and local units (with the exception of advertising teacher travel to conferences). See Harry Smaller, "Soldiers in the front line of battle': International Teacher Unions, the World Confederation of Organisations of the Teaching Profession, and the Cold War," History of Education Review, 38, 2, 
(2009): 28-42. Interestingly, even histories (critical or otherwise) of these organizations, while very detailed in many respects, also make little or no mention of their international involvement (see, for example, Maurice R. Berube, Teacher Politics: The Influence of Unions (New York: Greenwood Press, 1988); Marjorie Murphy, Blackboard Unions: The AFT and the NEA, 1900-1980 (Ithaca: Cornell University Press, 1991). Only Wayne Urban's more focused study of gender and race relations within the NEA makes mention of the organization's involvement at the international level, and its role in "facilitating" the post-Second World War "revival" of what would become the WCOTP, as well as its involvement in using the international organization to help the NEA "gain favourable attention" from the US government by supporting "professional" teachers' associations in nations around the world, in the hopes that they would "combat militant, more ideological teachers' groups which subscribed to international trade unionism and/or to communism" (Wayne Urban, Gender, Race, and the National Education Association: Professionalism and Its Limitations (New York: Routledge, 2000), 189).

54 The 1939 WFEA's six-week South American "conference cruise" was advertised as costing $\$ 800.00$, probably in the same range as the highly promoted tour to Tokyo for the 1937 mid-Depression gathering. By comparison, the report from the annual meeting of the Canadian Teachers' Federation Board of Directors held in Ottawa that summer included the following statement:

It is to be hoped that the appalling condition of educational affairs, which was reported by the delegates from Saskatchewan, is only temporary. In between two and three thousand school districts there are no collectable taxes. There is an actual famine in the matter of school supplies and equipment. For thousands of teachers the only source of income is the government grant with a maximum of $\$ 300$ [per annum] ("The Canadian Teachers' Federation," The B.C. Teacher 17/2 [1937]: 106).

55 For example, one impassioned plea from the secretary of the Secondary Teachers' Association of Bombay seemingly went unnoticed by WFEA officials:

I wish however to draw your attention to one [obstacle] which deserves to be made a world problem, I mean the securing of an economic wage to teachers. Recently they were discussing at Geneva the importance of giving a living wage to factory workers, but no body appeared to realize that teachers were a class of laborers - pardon me the expression - on whose efficiency depended the future of a nation. ... Many other countries have probably a similar grievance and the World Federation would do well to consider the advisability of making a recommendation to the League of Nations ..." (Proceedings, 1927, 812).

56 Pringle, Proceedings, 687.

57 The 1927 Proceedings include an interesting commentary, relating to the discussion of a report about textbooks, as to the "omission of the Labor Movement and the Woman Movement" in this report, and whether this might "lead to international misunderstandings" (229).

58 World Education, September (1937): 137. Of course, NEA officials would be reluctant to admit that many American teachers also endorsed a trade union culture - not only members of their own organization (judging from tensions on the floor at many annual conventions), but also, one can assume, those tens of thousands of teachers who voluntarily belonged to the competing organization, the AFL-affiliated American Federation of Teachers, during these times.

59 See, for example, March 15, 1935 letter from Ullrick to George, explaining that, "So far as any work has been concerned, these [Herman Jordan] committees have been a farce since $1929 . .$. Dr. Thomas [WFEA president] knew this also, but never appointed 
anyone in my place" (Selma Borchardt Files, Box 60, Walter Reuther Archives, Wayne State University, Detroit).

60 See, for example, Simon and Van Daele, International Teachers' Organizations; Goodman, Joyce, "Peace, Anti-Fascism, and Empire: Activism in the National Union of Women Teachers, 1920-1939," and, Carter, Patricia, "Henrietta Rodman and the Peace Movement: New York City Teachers in the World War 1 Era," papers presented at the 2013 Annual Meeting of the American Educational Research Association.

61 NEA, Conference Report, 12.

62 Proceedings, 1927, 781.

63 Enhancing bureaucratic, hierarchical, professionalized state schooling systems was certainly a major philosophical and professional goal of many officials and members of the WFEA (many of whom themselves were high-level school system bureaucrats). Two incidents in relation to the 1927 biennial conference held in Toronto might well exemplify these interests. First, the highly-orchestrated, pageant described above, with the purpose of presenting "a symbolic picture of the development of the world from savagery to civilization through the influence of education;" secondly, as a postconference teacher association journal editorial crowed, the conference had certainly "elevated the Canadian School System in the eyes of the international participants at the conference" (The Toronto Star, 13 August 1927).

64 NEA, Conference Report, 15. These values were not unique to NEA officials. In fact, Thomas's quotes here were replicated, almost verbatim, in the opening paragraphs of the UNESCO charter, adopted some two decades later. There may well have been a direct connection, given the NEA's strong involvement in promoting the founding of UNESCO, and particularly its educational aspects. See, for example, William G. Carr, Collecting My Thoughts (Bloomington: Phi Delta Kappa Educational Foundation, 1980).

65 Proceedings, 1927, 7. Even in 1925, the chairperson of the initial WFEA committee examining the Jordan Starr Report (a Superintendent of Schools from Idaho) was concerned the WFEA might be seen as supporting "anti-militaristic" views, rather than "serving the wide educational interests of the world" (1925 Proceedings, 833).

66 Pringle, Proceedings, 257-58.

67 World Education, September (1938): 14.

68 Ibid.

69 Pringle, Proceedings, 10.

70 The Christian Science Monitor, August 8, 1927.

71 WFEA, Proceedings of the 1935 Biennial Conference (Washington: WFEA, 1935), 423.

72 Ibid., 428.

73 Ibid., 430.

74 Proceedings, 1927, 777. In spite of Hardy's plea, the debate during the session continued for some time (understandably, given the perceived centrality of this issue to education and peace), until finally there was a motion to postpone the issue until the following biennial conference - at which time it was effectively tabled permanently.

75 Education World, March (1940): 190.

76 World Education, September (1938): 145.

77 World Education, September (1937): 135. Ironically, even WFEA's professed modus operandi, that of the "mutual acquaintance" and face-to-face engagement of educators across the international spectrum on issues of world peace, seemed not only not to be achieved, but perhaps, in reality, not even condoned. For example, as part of the official accolades of the purported success of the Tokyo conference, an editorial in the organization's journal glowed that

[t] he hospitality offered by individuals and by communities was generous and unstinted. The fact that a foreign war had been entered into did not curtail 
this hospitality. One evidence of the courtesy of our hosts is seen in the fact that this conflict was never mentioned either in public, or in conference or, as far as the writer is aware, in private conversation" (World Education, September (1937): 135.

78 World Education, September (1937): 134. 